BJHS: Themes 2: 235-263, 2017. C British Society for the History of Science 2017. This is an Open Access article, distributed under the terms of the Creative Commons Attribution licence (http://creativecommons.org/licenses/by/4.0/), which permits unrestricted re-use, distribution, and reproduction in any medium, provided the original work is properly cited.

doi:10.1017/bjt.2017.7 First published online 1 June 2017

\title{
The 'modern' management of rats: British agricultural science in farm and field during the twentieth century
}

\author{
KAREN SAYER*
}

\begin{abstract}
During the period from 1919 to 1970, rat killing was 'modernized': official, scientific, commercial, agricultural and county advisers sought 'rat control'. Scientific expertise on rat parasites and rat control circulated internationally. The risks posed to human health through plague, as traced by researchers who were already expert on the third pandemic, led in the UK to the Rats and Mice (Destruction) Act 1919; and the United Nations Conference on Food and Agriculture, at Hot Springs, Virginia, USA, 1943 informed its replacement, the Prevention of Damage by Pests Act 1949. Anticoagulants such as Warfarin developed in the USA at first sold widely in the UK, then later British research on resistance informed subsequent American research. This UK application of international policy and science paralleled the emergence of an official case at Parliamentary level for the national, multidisciplinary and multiagency approach to rats. Within the UK, animal ecologists under Charles Elton mapped rats in the emergent field of population studies; and new forms of economic costing at MAFF quantified the damage done to farm buildings and machinery and the consumption, soiling and contamination of food, seed and fodder in store. Yet nineteenth-century rat catchers already had an excellent and long-established grasp of rat behaviour, a necessity in either taking or executing their subjects. Though characterized as inefficient, picturesque and craft-based, that vernacular knowledge was reproduced and formalized in the twentieth century through empirical research and evidence-based practice, shaped by experiences at the intersection of human demand, the interests of the (wild and domesticated) animals that humans have preferred, and the endeavours of the rat.
\end{abstract}

\footnotetext{
* Leeds Trinity University, Brownberrie Lane, Horsforth, Leeds, LS18 5HD, UK. Email: K.Sayer@ leedstrinity.ac.uk.

This paper comes out of research funded by the Museum of English Rural Life Gwyn E. Lewis Fellowship; the author is very grateful to the staff at the Museum of English Rural Life, Reading, UK, for their assistance during the period of the fellowship. Paper first given at the Annual Conference of the BSHS, Swansea, July 2015, as part of the Travelling Rat, 1850-1950 panel session with co-speakers Neil Pemberton (Manchester University) and Kaori Nagai (University of Kent). I also wish to thank the following who saw earlier versions of the paper and offered valuable comment: the peer reviewers of $B J H S$; the audience members of the joint plenary with C. Griffiths at the Agricultural History Society annual conference in Lexington, USA 2015; and the Animal Histories seminar, Kings College London, January 2017. Thanks also go to Richard Thomas, reader in archaeology, for zooarchaeological advice and access to Rattus rattus and Rattus norvegicus reference skeletons in the Animal Bones Collections, held in the Department of Archaeology and Ancient History, University of Leicester.
} 


\section{Karen Sayer}

At first sight it might be supposed that rat destruction is a simple matter, not offering much scope for scientific research. Such, however, is not the case, for although rat destruction has been carried out for many years by empirical methods, no considerable success has been achieved. Of late years, however, scientists and health officials all over the world have given attention to the subject, and there are gradually being accumulated facts which, it is hoped, will lead to greater success in the future. C.L. Claremont, B.Sc. (Lond.), F.I.C., Research Chemist, Rat Destruction Branch (1921) ${ }^{1}$

To C.L. Claremont and the Rat Destruction Branch of Britain's Ministry of Agriculture, Fisheries and Food (MAFF), farm rats were the antithesis of livestock and the enemy of production. In a wartime leaflet, Kill Those Rats (c.1941), farmers were told they must 'starve them' by keeping them out of poultry houses and corn stacks, covering drains, and concreting the floors of food stores. They must 'keep them out' by rat-proofing buildings, blocking burrows 'with concrete mixed with broken glass and old wire netting', covering basement windows with galvanized wire netting, and putting 'thin metal sheeting ... over the lower parts of close-fitting doors'. Above all, they should 'destroy them. Poison them, gas them, hunt them, trap them'. To 'gas them' they were told to use cyanide power that gave off hydrocyanic acid 'in banks, hedgerows, rubbish dumps and other places in the open'. In wartime, killing rats was billed as 'an urgent war job, to be put in hand at once', ${ }^{2}$ but the list of methods was typical and long-standing: block, starve, trap and poison. Expel them from their rural lodgings, rather than give them shelter, because, as characterized in a post-war MAFF leaflet, You versus Pests (1957), issued by the Infestation Control division, they were said to '1) Consume the nation's food, 2) carry disease to human beings, 3) cause great damage to goods and property'. So farmers had to look for the signs of rat habitation: living or dead bodies; smears, tunnels, objects and holes gnawed; scats dropped; rat runs; accidental fires; consumed or spoiled food and other stores; urine smelled; scratching and vocalizations heard. ${ }^{3}$

In order to succeed, farmers and their occasional rat catchers always had to try and address the rats with an eye to the animals' behaviour. As Claremont suggested in 1921, the empirical observation of rats had long been the norm when attempting rat destruction. What his statement captures, however, is an early twentieth-century shift to a new, formal methodology grounded in capturing data, and one shaped by an international knowledge exchange within non-agricultural fields such as medical research and disease control. As he put it, 'scientists and health officials all over the world have

1 C.L. Claremont, 'The ministry's research (rat) laboratory', Journal of the Ministry of Agriculture (April 1921-March 1922, November 1921) 28, pp. 712-718, 712.

2 MAFF leaflet, Farmers! Kill Those Rats, London: HMSO, c.1941, MERL P4160 Box 1/01.

3 'You versus pests' Infestation Control Division, Ministry of Agriculture, Fisheries and Food, 1957, MERL PB4160, 34662-8. Rat incisors grow constantly, so to keep teeth in good condition they gnaw hard substances. Sometimes a trace of this type of rat activity can be found in the archive: 'A lead plant label acquired by the Museum from the Department of Agricultural Botany at the University of Reading. It has been nibbled on the edges by rats.' C. 1964, MERL, at www.reading.ac.uk/adlib/merl_objects/11765, accessed 20 July 2016. Rat activities were often tabulated in standard advisory texts after the war, e.g. Infestation Control: Rats and Mice, London, HMSO, 1946, on observing signs of rubbing, rat runs etc.; farmers were advised to bait or block. 
given attention to the subject, and there are gradually being accumulated facts' that brought with them the possibility of greater control. The circulation of this knowledge, plus additional work focused on the farm rat sponsored by organizations like MAFF, shifted the rat into the realm of agricultural science, ${ }^{4}$ and led in turn to the creation of new knowledges, expertise and jobs.

Farms, as well as producing food and raw materials, are also artefacts of human culture. As managed landscapes they vary in form across place with local topography, climate and environment, but also by selected farming practice, market and produce, policy and law. If, as Richard Yarwood and Nick Evans have argued, 'there is a need to recognise that farm animals have, quite literally, been constructed by people to fit into particular rural spaces', ${ }^{5}$ then there is also a need to address the ways in which these rural spaces have themselves been constructed. That process includes considering what has been excluded, or what humans have attempted to exclude. Rats as pest/vermin are one of many excluded organisms, and one (if we look at the rise of resistance to anticoagulants, for example) that in the process has responded physically to the act of exclusion, while anti-rat measures based in observation have literally shaped the architecture and built environment of the farm.

As Mathew Cragoe and Briony McDonagh have suggested, though enumerated by Roger Lovegrove in Silent Fields (2007), beyond the early modern period discussed by Mary Fissell and the field of agricultural history, rural 'vermin' have been understudied, especially in Britain. ${ }^{6}$ However, rat-dedicated studies like Jonathan Burt's (covering rats in all locations of all types) or Neil Pemberton's (which focuses on the interspecies history of Victorian rat catching in Henry Mayhew's London), ${ }^{7}$ have looked at urban, pet and other kept rats. Informed by environmental and ecological history, and zooarchaeology, much of the literature so far has focused on the entanglements of naturalized rats with epizootic medieval (or earlier) pandemics. There is also a literature

4 In the same way, Eleanor Ormerod (1828-1901) had captured the 'injurious insect' pest for the new field of economic entomology. See John Finlay Mcdiarmid Clark, 'Ormerod, Eleanor Anne (1828-1901)', ODNB; J.F.M. Clark, 'Eleanor Ormerod (1828-1901) as an economic entomologist: "pioneer of purity even more than of Paris Green”', BJHS (1992) 25, pp. 431-452; Suzanne Le-May Sheffield, Revealing New Worlds: Three Victorian Women Naturalists, London \& New York, Routledge, 2001.

5 Richard Yarwood and Nick Evans, 'Taking stock of farm animals and rurality', in Chris Philo and Chris Wilbert (eds.), Animal Spaces, Beastly Places: New Geographies of Human-Animal Relations, London: Routledge, 2000, pp. 98-114, 98.

6 Matthew Cragoe and Briony McDonagh, 'Parliamentary enclosure, vermin and the cultural life of English parishes, 1750-1850' Continuity and Change (2013) 28, pp. 27-50. Richard Lovegrove, Silent Fields: The Long Decline of a Nation's Wildlife, Oxford: Oxford University Press, 2007, pp. 1-4, 27-29, 44-45, 74-79; Mary Fissell, 'Imagining vermin in Early Modern England', History Workshop Journal (1999) 47, pp. 1-29. For examples of studies on rodent and other vermin (mostly rabbits) in environmental and agricultural history for the modern period see John Sheail, Rabbits and Their History, Newton Abbot: Country Book Club, 1972; Sheail, 'Wartime rodent control in England and Wales', in Brian Short, Charles Watkins and John Martin (eds.), The Front Line of Freedom: British Farming in the Second World War, Agricultural History Review, Supplement Series (2006) 4, pp. 55-66; John Martin, 'The wild rabbit: plague, policies and pestilence in England and Wales, 1931-1955, Agricultural History Review (2010) 58(2), pp. 255-276.

7 Jonathan Burt, Rat, London: Reaktion Books, 2006; Neil Pemberton, 'The rat-catcher's prank: interspecies cunningness and scavenging in Henry Mayhew's London', Journal of Victorian Culture (2014) 19 , pp. 520-535. 
of lab rats, co-produced by experimental science variously as components and bearers of information. ${ }^{8}$

What these studies demonstrate in accordance to the now established field of animal studies is not only that human cultures use other animals to think with, but also that human knowledge is generated in reference to other animals. ${ }^{9}$ This can certainly be seen in Llianne McTavish and Jingjing Zheng's study of rat control in Alberta, which addresses the interconnection between rat eradication and the human history of identification with a specific Canadian state in the 1950s. ${ }^{10}$ Animal, cultural and human geography and the history of science are raising important questions about the complex of power relations existing among humans and other animals on farms and their surroundings, with reference both to livestock, as in the work of Lewis Holloway on dairy cattle, and to those animals such as badgers and prairie dogs designated 'pests' by farmers. As is clear in the work of both Angela Cassidy on badgers and Susan Jones on prairie dogs, when agricultural texts authored new identities for the animals they described, this was part and parcel of housing them within human languages of control or conservation, of bringing them into human discourse for human purposes. ${ }^{11}$

Rats are not, of course, always classified as 'vermin' even in the West (c.f. the lab and the fancy and pet breeds), but as Stallybrass and White suggested, where images of the sewer were 'unstable, sliding between social, moral and psychic domains' ${ }^{12}$ the same has

8 Michael McCormick, 'Rats, communications, and plague: toward an ecological history', Journal of Interdisciplinary History (2003) 34, pp. 1-25; John McCann, 'The introduction of the brown rat (Rattus Norvegicus)', Somerset Archaeology and Natural History (2005), pp. 139-141; Kevin Reilly, 'The black rat', in Terry O'Connor and Naomi Jane Sykes (eds.), Extinctions and Invasions: A Social History of British Fauna, Oxford: Windgather Press, 2010, pp. 132-145; Anne Karin Hufthammer and Lars Walloe, 'Rats cannot have been intermediate hosts for Yrsinia pestis during medieval plague epidemics in Northern Europe', Journal of Archaeological Science (2013) 40, pp. 1752-1759, 1754-1755, 1759. Note: the zooarchaeological literature keeps being updated on the presence and absence of both $R$. rattus and $R$. norvegicus in the UK; lab mice are discussed by, for example, Karen Rader, “The mouse people": murine genetics work at the Bussey Institution, 1909-1936', Journal of the History of Biology (1998) 31, pp. 327354; lab rats are addressed by, for example, Burt, op. cit. (7), pp. 89-114, 170 n. 12; Michael E. Lynch, 'Sacrifice and the transformation of the animal body into a scientific object: laboratory culture and ritual practice in the neurosciences', Social Studies of Science (1988) 18, pp. 265-289.

9 For a related argument with reference to animal suicide see Duncan Wilson and Edmund Ramsden, 'The suicidal animal: science and the nature of self-destruction', Past \& Present (2014) 224, pp. 201-242, 203.

10 Llianne McTavish and Jingjing Zheng, 'Rats in Alberta: looking at pest-control posters from the 1950s', Canadian Historical Review (2011) 92, pp. 515-546.

11 Examples of recent work treating the farm in this way with reference to livestock production include Lewis Holloway, 'Subjecting cows to robots: farming technologies and the making of animal subjects', Environment and Planning D: Society and Space (2007) 25, pp. 1041-1060; Karen Sayer, 'Animal Machines: the public response to intensification in Great Britain, 1960-1973', Agricultural History (2013) 87, pp. 473-501; Michael J. Watts, 'Afterword', in Philo and Wilbert, op. cit. (5), pp. 291-302; Abigail Woods, 'Rethinking the history of modern agriculture: British pig production, c.1910-1965', Twentieth Century British History (2011) 23, pp. 165-191; Dawn Coppin, 'Foucauldian hog futures: the birth of mega-hog farms', Sociological Quarterly (2003) 44, pp. 597-616; Angela Cassidy, 'Vermin, victims and disease: UK framings of badgers in and beyond the bovine TB controversy', Sociologia Ruralis (2012) 52, pp. 192-204; Susan Jones, 'Becoming a pest: prairie dog ecology and the human economy in the Euroamerican West', Environmental History (1999) 4, pp. 531-552.

12 Pete Stallybrass and Allon White, The Politics and Poetics of Transgression, Ithaca, NY: Cornell University Press, 1986, p. 130. 
been true of that very disorderly animal the rat. The 'rat', just like the 'squirrel' in Britain as discussed by Hilda Kean, carries with it many layers of meaning within the borderlands of animal-human relations, ${ }^{13}$ and this capacity, like that of other animals, to function in the West as a screen on which to project human interests and qualities has been noted in histories such as Robert Hendrickson's More Cunning than Man, and utilized by philosophers like Michel Serres in The Parasite. ${ }^{14}$ But rats have few defenders because they have long been treated in art and literature, politics and satire, print and broadcast media as capable of taking on the most deplorable human characteristics, as outlined by Kate Soper in her classic study What Is Nature?. But what is key is that, as discussed by Steve Baker in Picturing the Beast, representations of rats have not simply defined humanity's best features through inversion. The rat's image has also had the very real effect of establishing in Western culture the inferiority of actual rats relative to human beings and this has contributed to their physical destruction. Though we cannot access an unmediated 'real' animal, those representations, as Baker argues, have real effects, ${ }^{15}$ in the case of farm rats: death by starvation, trapping and poisoning, and disruption of their habitual routes, access to nests, carefully defended territories, families and even reproduction.

However, though a peripheral animal from the human point of view, which exists on our margins, the rat inhabits and crosses human boundaries (such as hedges or streams near farm buildings, rivers and waterways) to seek out its own opportunities. In so doing, by shaping our actions in response, such as the placing of blocks made from concrete, glass and wire into our buildings, it makes those margins, peripheries and boundaries more visible. During the twentieth century, in the case of British country rats, as vermin a quintessentially peripheral and marginal animal, the built structures of those farms that were thought of as 'well managed' - a quality normalized by agriculturalists as 'good' and by the aesthetics of the most desirable farm buildings as 'modern' - and the adoption of 'Hygienic measures in livestock management' were all also in part informed by rats, ${ }^{16}$ who pushed back against the human boundaries to make their own spaces. Disadvantaged by farm 'hygiene', like other unwanted organisms framed as carrying disease or as a threat to food security, the rats also remained part of human agricultural practice by making work for farmers. Rats have thus helped shaped the material and managed spaces, look and feel of the modern farm.

Drawing on a range of qualitative material, from articles in the farming press, agricultural journals, standard agricultural texts and advisory literature, through to the popular and scientific press, film, official enquiries and scientific reports, this article focuses on

13 Another example (not on rats) is Hilda Kean, 'Imagining rabbits and squirrels in the English countryside', Society \& Animals Forum (2001) 9, at www.societyandanimalsforum.org/sa/sa9.2/kean.shtml, accessed 25 February 2014.

14 Robert Hendrickson, More Cunning than Man: A Social History of Rats and Men, New York: Dorset Press, 1983; Michel Serres, The Parasite, trans. L.R. Schehr, Baltimore: Johns Hopkins University Press, 1982.

15 Kate Soper, What Is Nature? Culture, Politics and the Non-human, Oxford: Blackwell, 1995, p. 86; Steve Baker, Picturing the Beast: Animals, Identity and Representation, Manchester: Manchester University Press, 1993, pp. 148-149, 154-156; Burt, op. cit. (7), p. 49.

16 D.H. Robinson (ed.), Fream's Elements of Agriculture, 14th edn, London: John Murray, 1962, pp. $711-712$. 


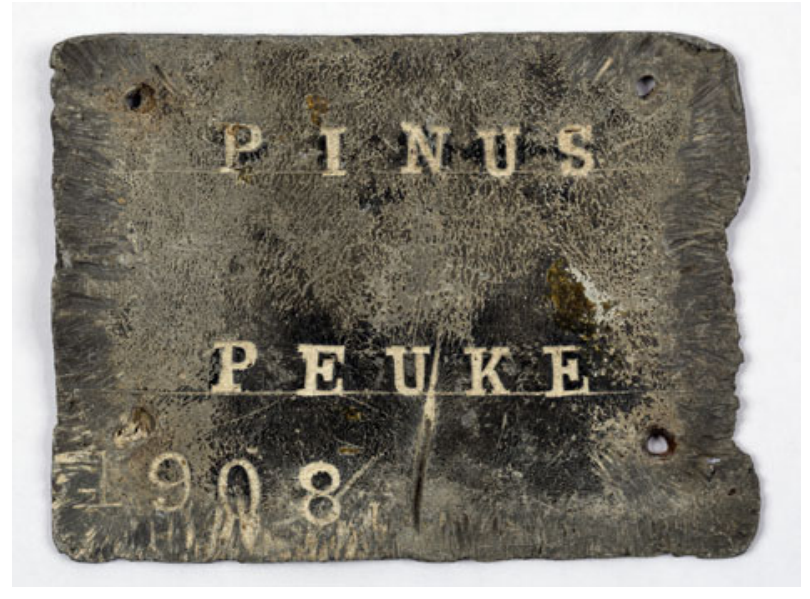

Figure 1. 'A lead plant label acquired by the Museum from the Department of Agricultural Botany at the University of Reading. It has been nibbled on the edges by rats'. Courtesy of MERL.

rhetorics of rat 'destruction' and 'control' in Great Britain c.1910 to 1970. It first addresses the way in which farm rats came to the British public's attention via an outbreak of epizootic plague in Suffolk c.1906-1918; then, during the Second World War and after, the focus was on rats as farm animals, when their management was once again shaped more by the changing context of food production than by disease. Reading for farm rats within the human archives, ${ }^{17}$ we also find other animal histories: cats and dogs harnessed to kill rats; cattle poisoned by 'sweet clover disease'; foxes, barn owls, red kites and kestrels poisoned because they predated country rats. Farming does not just involve the management of the rural space(s) of the farm. It is an integrated system and its maintenance involves managing much that is 'off-farm'. It will be shown that, as well as through physical control of rat's bodies, however, increasingly that process of management was grounded like agricultural production in quantitative methods.

When we follow the human subjects in this period, the 'vernacular', craft knowledges look very similar to the new forms of knowledge framed as 'scientific expertise'. Though dismissed in 'modern' accounts as picturesque, both craft and science used empirical methods, as Claremont noted, in order to keep rats at bay. Whenever a human tried to control rats, they had to act according to the rats' behaviour, and therefore certainly needed to act on observation. Rat behaviour included responses to attempts at control, such as extreme distrust of new sources of food, and acquired physiological resistance to anticoagulants. The human response was a stepping up of control through the use of statistical data, a literal accounting for rats, interwoven

17 Etienne Benson, 'Animal writers: historiography, disciplinarity, and the animal trace', in Linda Kalof and Georgina M. Montgomery (eds.), Making Animal Meaning, East Lansing: Michigan State University Press, 2011, pp. 3-16, 11-13. 
with farm records and the emergence of labour efficiency on the farm. Rats have therefore shaped both the craft and the science dedicated to their erasure.

\section{Mapping rats moving across farm and field}

The extreme food shortages of the sixteenth century saw many rodents alongside other 'vermin' killed for reward under the oversight of the parish, due to 'vermin' directives aimed at protecting grain. Long before the twentieth century, rat 'destruction' was therefore already an established part of farming practice. Under the term 'ratting', it was woven into the local economy as a seasonal necessity. At threshing time, boys and men went ratting when the rats ran out of the corn stacks, and this complemented the regular and (from an agricultural point of view) necessary work of the expert rat catcher undertaken year-round, ${ }^{18}$ while rat and sparrow clubs paid their competitive members per rat tail for the same reason. ${ }^{19}$

By the turn of the nineteenth to the twentieth century there was therefore already an extensive and long-established body of experiential knowledge and published empirical material on tackling rats, aimed at both specialists and general readers. There were soleauthored examples such as Sir James Wright, Bart., Observations upon the Important Object of Preserving Wheat and Other Grain from Vermin (1796), which focused on rats eating stored grain, and possible structural adaptations designed to address rat 'cunning' that would tackle it through prevention (not just killing rats). A hundred years later we find H.C. Barkley, Studies in the Art of Rat-Catching (1896), and then Mark Hovell, Rats and How to Destroy Them (1924), who advised that traps be placed in hedges and streams year-round. ${ }^{20}$ These monographs blended into the emergent literature that came to be published by specialist organizations, such as W.R. Boelter, The Rat Problem (1909), published under the auspices of the Incorporated Society for Destruction of Vermin, and dedicated print and visual and materials aimed at farmers by institutions like the Board of Agriculture (later MAFF), the Royal Agricultural Society of England, commercial producers of rat traps and vermicides, and farming magazines like Farmer's Weekly and Farmer and Stockbreeder. ${ }^{21}$ As the

18 The census data suggest that there were a few professionals, classified under the heading X(1) 'vermin destroyer' in 1851. At the time there were 1,732 males of all ages in England and Wales, and 516 in Scotland. The total women in this classification at the same time, for the whole of Great Britain etc., was five. 1851 Census, pp. ccxxiii, ccxxix, ccxxvi. By 1921 the professional operators have been subdivided into 'Rat Destroying \& Trapping (Agricultural)' code 019, and 'Vermin Destroying (non-agricultural)' code 809. However, 019 was 'Other Agricultural Industries' and 809 'Other Industries', so the total figures given 6,492 and 6,904 respectively - probably cover more trades and professions than rat catching. 1921 Census, pp. $5,13,16,206$.

19 Cragoe and McDonagh, op. cit. (6). 'Vermin' has historically been a very elastic category. Note: rat and sparrow clubs generally gave a penny a tail, which could form a useful additional income, as recorded in Charles Kightly, Country Voices: Life and Lore in English Farm and Village, London: Thames and Hudson, 1984, pp. 19-20.

20 For example, see the advice given by Mark Hovell, Rats and How to Destroy Them, London: J. Bale and Danielsson, 1924.

21 James Wright, Observations upon the Important Object of Preserving Wheat and Other Grain from Vermin, Covent Garden: Cooper Graham, 1796; H.C. Barkley, Studies in the Art of Rat-Catching, 


\section{2}

period progressed, so the range of advice became more specialized. This was often selfrepresented as more 'modern' via the use of new methods of destruction such as 'gas' (water-reactive powdered compounds of cyanide), yet, driven by the need to act on the basis of rat behaviour, alongside commercial interests in some cases, re-coded old empirical knowledge, itself based on watching rats, as 'new', drawing on scientific methods of observation and quantification.

A typical, popular and therefore witty discussion can be seen in a long and careful description of rats and their behaviour in Chambers's Journal, which sought to outline the rat's better qualities as well as its worst in 'justice to an object of such universal dislike'. 'When in a state of liberty', the journal states, for instance, 'rats appear to be free from disease of any kind - a fact to be perhaps attributed to their great cleanliness, all their leisure time being spent sitting on end, cleaning their fur'. ${ }^{22}$ Such observations offer us traces of rats in history: evidence that they have been watched, as well as a description of what has been observed. This is coloured in a popular text like Chambers's by human irritation, but we still see incidental evidence of rats' activities in expressive tallies of their effects on human lives and materials, such as the 'perpetual annoyance' in the farmhouse of their 'boring holes in boarded floors, undermining stone pavements, gnawing harness, killing chickens and ducks', and appetite for 'grain, leverets and game of all kinds'. ${ }^{23}$ Though country rats in particular, Pemberton has argued, were not thought diseased at the time (and were often caught in the Victorian period for use in sport by urban rat catchers), ${ }^{24}$ they were still considered 'nuisance' enough to leave traces in our histories, and to warrant sufficient human intervention to lead to the production of expert knowledge and creation of roles, but not enough to require statutory tools.

In the Victorian period, however, only a select few of these experts were valued as such by the populace at large. It was commonplace at the time to see the country rat catcher as being 'usually a man of few words, and those few not always to be relied upon ... a compound of the gipsy, gamekeeper, and poacher ... Looked upon with suspicion by all who employ him'. Their urban counterparts seem to have been understood (within a typical rural-urban binary) as quicker, if normally dishonest: in 'London, an honest rat-catcher is looked upon as a rarity indeed ... Nevertheless, such are to be found'. ${ }^{25}$ Because it was positioned in the non-farming public's perception as something of an isolated, oldfashioned country pastime, the activity of destroying rats and those associated with it therefore functioned in periods preceding this essay as something of a boundary marker between rural and urban, the new and the old, science and art, modernity and tradition, just as the image of country rats as clean rather than diseased marked out the qualities of rural and urban human life. This changed with the emergence of concerns

London: John Murray, 1896; W.R. Boelter, The Rat Problem, London: John Bale, Sons and Danielsson, 1909.

22 Anon., 'Rats', Chambers's Journal of Popular Literature, Science and Arts, January 1854-November 1897, 18 August 1860, pp. 110-112, 111.

23 Anon., op. cit. (22) pp. 110-111.

24 Pemberton, op. cit. (7), pp.

25 Anon., op. cit. (22), pp. 111-112. 
about plague. In the early twentieth century, it was the threat of a modern pandemic that brought the country/farm rat to the wider attention of the urban public as something more in metropolitan eyes than a distant and occasionally picturesque rural nuisance chased by boys and unreliable men, or possible object of illegal sport. ${ }^{26}$

When plague was pinpointed as having occurred in rural Britain in 1910 the link between bacillus, fleas and rats was still only newly accepted, the bacterium Y. pestis having only been discovered in Hong Kong by Alexandre Yersin in 1894, and the possible transmission route of Xenopsylla cheopis to humans from the black rat only having been proposed by Paul-Louis Simond in 1898. The hypothesis remained contentious when tested in Australia in 1901. ${ }^{27}$ Yet, in October that year, four people in Frenston, Suffolk, died of what was suspected to be 'pneumonic plague', and further investigation revealed that East Anglian rats were implicated. ${ }^{28}$ It was also found nearby in two hares, a ferret, dogs and a cat. Earlier outbreaks in the area were subsequently discovered to have taken place in some farm cottages by the river Orwell between December 1906/ January 1907 and December 1909/January 1910. There was another occurrence in October 1911 and later two final cases in June 1918. In all, it resulted in sixteen human fatalities. Thousands of rats were killed in the process of determining the extent of the disease. ${ }^{29}$ Though this had been preceded by a much higher incidence of plague in the port at Glasgow in August-September 1900, when sixteen victims died of plague, and what were reportedly similar outbreaks in Liverpool in 1901 and Govan, Scotland, in 1903, 30 and by efforts to tackle plague in the ports and cities of south China and Hong Kong from 1894, ${ }^{31}$ it was this 1910 outbreak in rural England that was cited in the Parliamentary debates that led ultimately to the Rats and Mice (Destruction) Act 1919 (54 \& 55 Vict. c. 76). That Act tasked every citizen with a legal obligation to remove rats from their property. In order to address the twentieth-century history of country/farm rats, it is therefore necessary to see how rats and their country habits were framed during the outbreak of plague.

The progress of what eventually became specific anti-rodent (rather than generic 'vermin') legislation was typical of the process in which legislative intervention was enacted after a period of laissez-faire approach. First, in this instance, plague having been reported in Suffolk (its presence in other countries and its presence on shipping

26 Hansard, Commons Sitting of Monday, 23 May 1898, records a question raised about a case of a rat, on a string, being worried by dogs, and if this was against the law; this tested and therefore established the law - so that it clearly related to domestic animals - more than it changed the definition or place of the rat in human culture.

27 Hufthammer and Walloe, op. cit. (8), p. 1752; Myron Echenberg, Plague Ports: The Global Urban Impact of Bubonic Plague, 1894-1901, New York: New York University Press, 2007, p. 265.

28 'Reports and papers on suspected cases of human plague in East Suffolk and on an epizootic of plague in rodents', Reports to the Local Government Board on Public Health and Medical Subjects (new series, no 52), London: HMSO, 1911, p. ii.

29 David Van Zwanenberg, 'The last epidemic of plague in England? Suffolk, 1906-1918', Medical History (1970) 14, pp. 63-74.

30 Hufthammer and Walloe, op. cit. (8), p. 1757; Royal Commission on the Poor Laws and Relief of Distress, Appendix Volume VI, Minutes of Evidence (95th to 110th days and 139th and 149th days), with appendix, Cd. 4978, 1910.

31 See Echenberg, op. cit. (27), for a global history of the third pandemic. 


\section{4}

Karen Sayer

already having been discussed by bodies like the Association for Schools of Public Health), the subject was addressed and returned to by national papers such as The Times, concerned about the risk of infection spreading from East Anglia to densely populated urban districts, and by publications overseas. It came to the attention of bodies such as the Royal Institute of Public Health, and was raised in Parliament. ${ }^{32}$ Tapping into the international circulation of knowledge about rats, which had already been generated by the pandemic, the new expertise and membership of emergent cadres of specialists that had formed around plague and rats both overseas and at home were drawn upon. ${ }^{33}$ For example, Dr R. Bruce Low, who served for twenty-three years under the auspices of the Local Government Board on Public Health and Medical Subjects, the Advisory Board of the Army Medical Service, and related committees, wrote annual reports on plague from 1902 that were 'an unrivalled storehouse of information concerning' plague; Dr Bulstrode, the medical inspector of the board who wrote up a detailed summary of events in the 'Report on suspected pneumonic and bubonic plague in East Suffolk and on the prevalence of plague in rodents in Suffolk and Essex', wrote reports and papers on suspected cases of human plague in east Suffolk and on an epizootic plague in rodents (1911); and Dr Martin, then director of the Lister Institute, who led the investigation, had previously been chair of the Advisory Committee of the India Office on Plague. There was a high level of cooperation at the institutional level, as this suggests. The Lister Institute both received samples for testing and sent staff to Suffolk to examine the rats and 'their special flea parasites'. The significance of the event can be gauged from the fact that because some local authorities and occupiers of property were less active or cooperative than others, the Local Government Board, with advice from the Board of Agriculture, issued an order giving power to, and requiring, the local sanitary authorities to exterminate the rats and prevent them from entering property. As a result of this inter-agency and nationally directed activity, the outbreak was contained. ${ }^{34}$

What is most striking about this process, however, and worthy of focus here, is the renewed attention paid by these largely urban experts to the rats and the precise nature of the risk posed by their behaviour in the countryside, not just in town or port. Though in 1910 the subject of rat 'destruction', as it was framed at the time, was not deemed by Parliament to be a matter for direct or centralised state intervention, it was not so much the arrival of plague, or even the discovery of plague-carrying fleas on rats (who were already subject to control on ships in ports because of the third pandemic), but the particular risk posed to human health by the potential movement of

32 For example, 'The menace from rats', The Times, 11 November 1910, p. 9. The topic of plague was reported by organizations such as the Association of Schools of Public Health, for example 'Japan: report from Yokohama Inspection of Vessels. Fumigation of vessels for rat destruction. Plague. Meeting of sanitary officers of the empire', Public Health Report (1896-1900) (4 June 1909) 24(23), p. 789. As it progressed, the subject also attracted the attention of the press overseas as well, for example America (25 February 1911), 4(20), p. 459.

33 Annual Report of the Medical Officer of Health to the Local Government Board Report for 1911-12 (Local Government: Medical Supplements), Cd. 6341 Vol. 36, p. lxxix.

34 'Reports and papers on suspected cases of human plague', pp. iii-v; 'Rat plague in East Anglia', House of Lords Hansard, Lords Sitting of Tuesday, 22 November 1910, Fifth Series, Vol. 6, cc. 826-828. 
the animals travelling around rural areas, that escalated the issue to the national level and resulted in a newly focused re-visioning of the rat. As stated by Lord Lamington, sharing knowledge of rat behaviour based on his experience in India as governor of the 'plague-infected city of Bombay' from 1903 to 1907, in the debate recorded at the time in Hansard, a 'rat does not confine its operations to the district of one local authority. That is the whole danger' ${ }^{35}$ And this alone was enough to necessitate a new, centralized and later legislated approach to rat control: the limit of a specific rat law was an effect of suddenly paying new lab-centred attention to rats and rat conduct, that law grounded in the discourse of disease and control.

It was quickly discovered that the 1910 Suffolk plague outbreak was due to the brown rat (Rattus norvegicus), which largely replaced the black rat (Rattus rattus) in Europe from the mid-eighteenth century: no black rats were discovered in 1910 in Suffolk, a point that was periodically reiterated long after the event. ${ }^{36}$ The black or ship rat climbs into lofts and lives in houses in close contact with human beings, and the brown rat prefers to keep its distance by burrowing and living in tunnels. It is probable that black rats, present in Great Britain at least from the Roman period, were never numerous on farms, though they are still found in some port cities, while brown rats introduced in the 1720 s only became a nuisance from the late eighteenth century. ${ }^{37}$ But during the period in question and then during the First World War and the interwar period, all rats (black and brown) became characterized as noticeably un-English. Though many accounts were at pains to distinguish between the two and their histories, the rat, a homogenized threatening invasive 'menace' when associated with plague, or in wartime, highlighted as ever the qualities that the nation sought to deny or escape, added to by the allegorical use of rat images in which the rat (used in one cartoon as a rather pathetic-looking victim of the healthy British bulldog) was equated with the enemy. ${ }^{38}$

After nine years, in 1919, just after the end of the First World War, Lord Aberconway then framed his introduction to the second reading of his Rat Destruction Bill within the House of Lords, as being crucial at the national level to post-war reconstruction. This was, he said, because of property damage, but, at least for the purposes of rhetoric, he still stressed the identification of rats as carriers of 'plague bacillus'. Harnessing the interest of the Lords as agriculturalists, alongside the threat of plague, he drew on the

35 'Rat plague in East Anglia' op. cit. (34), p. 740.

36 'Reports and papers on suspected cases of human plague', p. vi; see also H.H. Donaldson, The Rat, Philadelphia: Wistar Institute, 1924, cited by Charles Elton, Animal Ecology, New York: The Macmillan Company, 1927, pp. 52-53, which reiterate this point.

37 Date of first record for the brown rat according to DEFRA is 1720 , and 'The GB pre-breeding population was estimated to be at least 6.8 million animals in 1995'. DEFRA, 'Brown rat, Rattus norvegicus', at www. nonnativespecies.org//factsheet/factsheet.cfm?speciesId=2979, accessed 20 July 2016. Date of first record on DEFRA for Rattus rattus is 250; its current population is small and its range limited to seaports. DEFRA, 'Ship rat, Rattus rattus', at www.nonnativespecies.org/factsheet/factsheet.cfm? speciesId=2980, accessed 20 July 2016.

38 Alfred Moore Hogarth, The Rat: A World Menace, London: John Bale, Sons and Danielson, 1929; A.G. Racey: cartoon, $32.2 \times 33.2 \mathrm{~cm}$, pen and ink, 1915: 'A British bulldog wearing a collar on which is inscribed "British Navy" is holding a rat on which is written "Blucher" in between his teeth', Wellcome Library, Iconographic Collection 571935i, at http://wellcomeimages.org/indexplus/image/V0049555.html, accessed 20 July 2016. SMS Blücher sank on 24 January 1915 at the Battle of Dogger Bank. 
effectiveness of the 1910 response, and argued that scientists, bacteriologists, farmers and agricultural societies supported him. The public interest was, he argued, endangered not only because of the health risks (in fact, he referred to them as 'these plague carriers'), but also by the rats' well-known impact on agriculture and therefore on the country's food supplies (eating roots, grain, seed corn and hens' eggs, and attacking young birds and animals), and damage to infrastructure (he suggested that rats had been responsible for gas explosions by eating through lead, much as they have been said more recently to cause 50 per cent of farm fires by eating through electrical insulation ${ }^{39}$ ). In Norfolk, Suffolk or Hampshire, Aberconway said,

you will find the rat in countless millions. If you go there in December or January when the winter wheat has been put in, in a big field of 100 acres you might see straight roads, hard beaten tracks, terminating in central stations - roads that remind one of Roman roads with a castrum in the middle, and all round the field you see the ground torn up in innumerable little heaps of soil. That means that the rat has been digging up and eating the seed corn. You do not see rats in the daytime, but if you go along the hedgerows you hear them squealing at every step. That is the conversation of the rat. ${ }^{40}$

In Aberconway's speech, the rat, taking on human characteristics in its vocalizations, attacked modern farming; it undermined, at night, the most civilized of England's agricultural processes. Such a statement (particularly following directly as it did from the second reading of the Anglo-French Treaty (Defence of France) Bill) was enormously evocative of the technologies of trench warfare. Even so, in supporting the reading the House of Lords referred to the work done in Belgium, Denmark and Germany to control rats. A similar British response at the national level was in their view the only way to tackle the rats' literal, but also unpatriotic, 'migratory', 'nomadic' and 'predatory' habits: the rat escaped national boundaries. In reply, Lord Ernle, the president of the Board of Agriculture and Fisheries, stated that the debate, with the reading, 'assists us very largely in creating a proper public atmosphere' for the government to propose its own bill. As such, and also building, as environmental historian John Sheail has argued, on the First World War food conservation campaign, ${ }^{41}$ it had cross-party support. ${ }^{42}$ Indeed, in the face of food conservation, the focus on the disease-carrying capacity of rural rats largely fell away. Despite occasional reference to their capacity to carry disease, as in the 1950s MAFF leaflets, the next scientific study addressing the potential of rural rats to carry parasitic species and transmit zoonotic diseases, despite the cultural associations, was published in 1995 by J.P. Webster and D.W. Macdonald (members of the Wildlife Conservation Research Unit, University of Oxford). Webster and Macdonald found that each of 510 brown rats live-trapped on eleven UK farms tested positive for, simultaneously, two to nine

39 Alan Buckle, 'Rat control 1: impact on farm', at http://academy.fwi.co.uk/Courses/Livestock/Rat-control/ Rat-control-1-impact-on-farm, accessed 13 February 2013; he also states, 'Based on today's prices, the damage on farm caused by rats is estimated to cost the UK farming industry $£ 14$ to $£ 28$ million a year.'

40 'Rat Destruction Bill [H.L.]', House of Lords Hansard, Lords Sitting of Thursday, 24 July 1919, Fifth Series, Vol. 35, c. 1038.

41 Sheail, 'Wartime rodent control', op. cit. (6), p. 56.

42 'Rat Destruction Bill [H.L.]' op. cit. (40), cc. 1037-1045. 


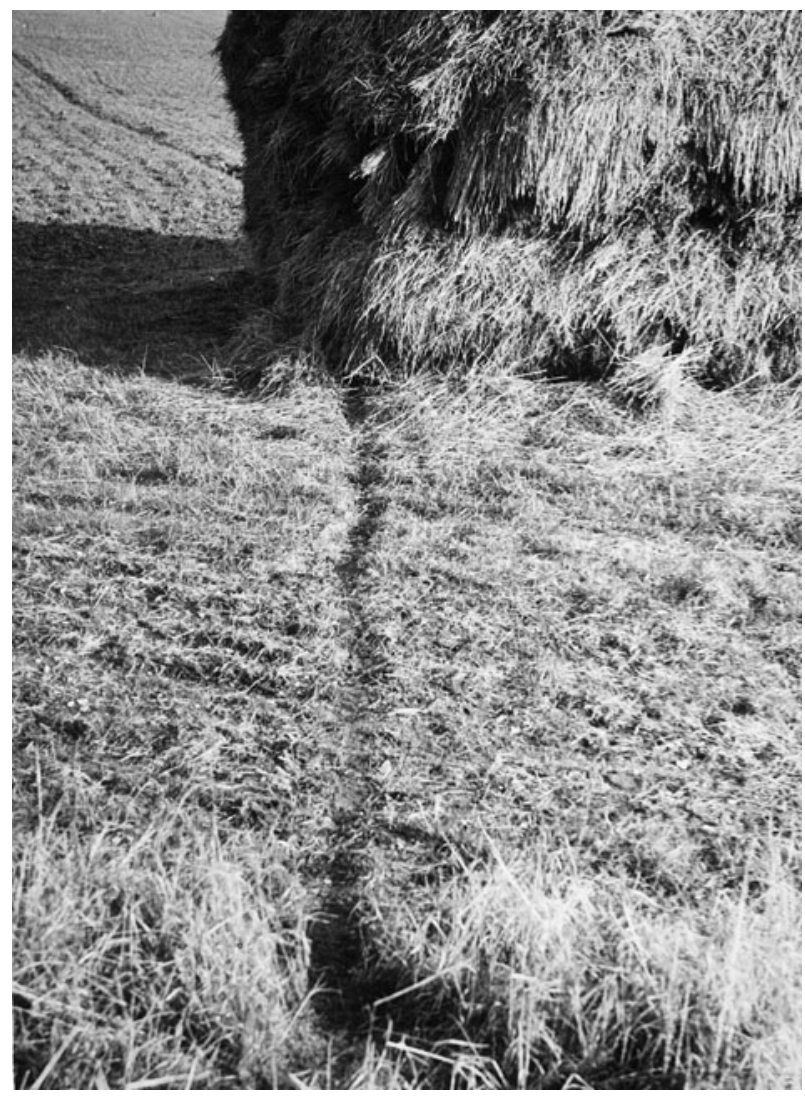

Figure 2. 'Black and white photograph of wheat rick in bad condition, with a rat run', Farmers' Weekly (1940), Eric Guy, courtesy of MERL.

potentially zoonotic parasites each. On the basis of their study, which showed that the rats were implicated in the spread of zoonotic disease among humans and livestock in rural areas, they recommended 'veterinarians and farmers should be aware of the disease risk that rat infestations may present to both themselves and their livestock, and more effort should be made to control the rat carriers' ${ }^{43}$ From the Second World War until 1995, however, the country rat featured as it had in the early modern period, principally as a threat to human food production or stores, and as an economic problem to be controlled through quantification.

43 J.P. Webster and D.W. Macdonald, 'Parasites of wild brown rats (Rattus norvegicus) on UK farms', Parasitology (1995), 111, pp. 247-255, 254. They tested the rats (not all of whom were killed) for macroparasites and microparasites, i.e. from fleas and lice to viruses and bacteria, many of which 'contribute to zoonotic disease in humans and domestic animals in a farm or rural environment'. Ibid., pp. 247, 248, 253. 


\section{Rat destruction/rat control}

Fitting into Knight's pest discourse, ${ }^{44}$ rats can suddenly appear in great numbers, as testified by a cooper 'who was pursued by hundreds of rats at dawn one day in Hampshire' - a tale told to Sir James Wright's bailiff. ${ }^{45}$ Wright captures human-rat histories, such as that of the rats which chased a man who shot at 'a great assemblage of several thousand ... progressively going before him', and the impact of rats pursuing their own livelihoods, though framed by the human response. Not only did rats eat 'voraciously', for instance; they also had 'sagacity' in view, because, as Wright records, some rats were observed climbing a tree overhanging a stack and dropping onto it from a height of 'three yards'. It was this type of action that led Wright to design his new 'pendant frames' in his Patent Artificial Slate. ${ }^{46}$ However, the text also attempts to assess how much economic damage farm rats might do ordinarily, showing that this approach was already extant at the point at which Aberconway spoke. By seeking legitimacy and authority for his product, Wright offers us an example of an emerging form of control through quantification based on observation and comparison, within the discourse of agricultural improvement.

Writing in the 1790s, Wright (who wanted to sell a Patent Artificial Slate he developed for use on haystacks and wheat stacks) relates that a farmer in Sussex, of several hundred acres, killed 450 rats a year, based on his bailiff's reckoning, and he assumes that 'each rat eats full an ounce of corn a day: I calculate from this position ... the barns contain corn $1 / 3$ part of the year, say 120 days, which multiplied by 450 , makes 540,000 ounces'. He then works out an estimation of parishes that grow corn and 'multiply my parish loss by 5,000, and the product will be 2,700,000,000 ounces, which I conceive to be equal to $168,750,000 \mathrm{lbs}$ in weight, which ... will make a loss of grain throughout the kingdom of 16,850,000 bushels', based just on the 450 rats that have been caught, let alone 'the living ones that evaded his bailiff's traps'. Wright himself argues that rats eat more than an ounce of grain a day, 'as I procured a half-grown rat, and kept him seven days and a half upon wheat; when he eat eight ounces'. Granted, Wright was not a disinterested observer, as he had a product to sell, but such testimony shows that experiments took place with live farm rats (in which a young farm rat ate grain and produced knowledge) in periods of agricultural improvement before the twentieth century. Wright worked via correspondence, in the style of an eighteenth-century natural scientist, reporting others concerned about the 'depredations of those voracious animals' to gain comparative material.

During the 1919 debate the figures provided by Aberconway were questioned, and by this point farmers seemed more concerned about the rather more visible damage being done by rabbits than by rats. However, it is clear from this immediate post-First World War debate that politicians were more than capable of using the capacity of the rat to carry the worst human features to considerable symbolic effect, which resulted

44 John Knight, Natural Enemies: People-Wildife Conflicts in Anthropological Perspective, London: Routledge, 2000, Introduction.

45 Wright, op. cit. (21), pp. 12-13.

46 Wright, op. cit. (21), pp. 13-14, 17-19. 
in increased rat mortality. When it finally passed into law, having been re-presented by the government and given royal assent on 28 December 1919, the bill became the Rats and Mice (Destruction) Act 1919 (54 \& 55 Vict. c. 76), which could result in a fine of five pounds if an occupier failed to act to rid property of rats and mice, though the latter seem to have rarely featured in actual action against vermin. If this was not tackled in the time specified by the local authority, then that authority could recover its expenses for the work. Ships in port were also covered by the law - ships' captains being treated, by the legislative framework the Act established, as occupiers of land - and there was advice on how to tackle rats in urban as well as rural environments. Rats officers were to be employed to regularize the Rats Order and formally enforce it, and if they were obstructed then occupiers could be fined up to twenty pounds. The press received this with little fanfare, but disseminated the Act's main provisions and recognized that rat catching was to be put on some kind of official footing, which according to a Manchester Guardian article might mean the loss of the picturesque rat catcher. That rat catcher (elevated relative to the Chambers's Journal piece) was 'a mine of field and wood craft': instant nostalgia generated a sense of loss and regret, but the rat catcher of old was not modern. ${ }^{47}$ What was to be done, as stated in the Manchester Guardian, was all about public communication, not specialization: 'it is further suggested that the Act should be widely advertised by means of posters giving directions as to the most effective methods to be adopted individually and collectively by those who have rats or mice on their premises'. A 'draft of a poster' was therefore provided, which stated that collective action was best, and that dead rats should be destroyed by burning, old baits removed and owners of livestock warned of rat catching in process. ${ }^{48}$

In this way, rats and mice became subject to new, formal, legislative controls, but much of the effect of the legislation depended on the ongoing work of rhetoricians and the dissemination of information by local authorities rather than official, specialist agents of rat control. ${ }^{49}$ As John Sheail has observed, the aim of the Ministry of Agriculture after the 1919 Act was therefore to engage the general public in the process, not to systematically control rats. ${ }^{50}$ The aim was not really to impact in any significant way on the rat population, despite the advice about rat killing, but to raise awareness of the problem and emphasize the shared responsibility of tackling it. This was successful: in the words of Minister of Agriculture Sir Arthur Boscawen in 1921, the 'necessary anti-rat atmosphere' had been created by the new Act. ${ }^{51}$ The actual methods of control, however, remained embedded in the established practices and

47 'Destruction of rats: provisions of the new bill', Manchester Guardian, 30 December 1919, p. 12; 'The ratcatcher', Manchester Guardian, 21 July 1920, p. 14.

48 'Destruction of rats: provisions of the new bill', Manchester Guardian, 30 December 1919, p. 12; 'The ratcatcher', Manchester Guardian, 21 July 1920, p. 14.

49 'Damage by rats', House of Commons Hansard, House of Commons Debate, 29 July 1927, Fifth Series, Vol. 209, cc. $1665 \mathrm{~W}$.

50 Sheail, 'Wartime rodent control', op. cit. (6), p. 56.

51 MAFF, HC Deb, 19 April 1921 vol. 140, cc. 1731-1842, Minister of Agriculture (Sir Arthur Boscawen), p. 1741. 
vernacular knowledges of the rat catchers, framed by the new focus on disease regardless of location.

Government continued to work in raising the profile of the rat during the interwar period in the form of 'National Rat Week' (in November), advertised in the press, via posters and through cinemas. In a 1920 Pathé film entitled London - Kill That Rat!, 'Government asks everyone to assist during Rat Week to exterminate this dirty, disease-carrying, destructive pest'. A similar film made in 1919 had focused on the Borough of Leeds and what was being done there to gas rats, the film itself showing gassing taking place in a rural rather than an urban setting. Local boroughs reported their activities, such as giving out free rat poison and traps, to MAFF, which continued to sponsor the week in rural and urban areas during the Second World War. ${ }^{52}$ MAFF set up its own Research (Rat) Laboratory, led by Claremont, who published on the lab's activities in the monthly Journal of the Ministry of Agriculture and presented research findings at the Conference of Rat Officers. Much of that work was dedicated to looking at red squill as a poison that might be presented in a palatable yet longlasting form to rats, at a lethal dose, without likelihood of causing harm to other animals, including humans. The lab had a 'factory' attached, all on 'the top floor of one of the old blocks at Mount Pleasant Post Office ... in what was once part of the Cold Bath Prison', London, which employed Claremont himself, plus a lab assistant, two men and a boy. A slightly ramshackle and evidently low-road affair, there was equipment in the lab 'so far as funds permit', and 'mixing machines, a dough brake, and biscuit cutter $\ldots$ a large gas-fired oven [and] a percolator' in the factory. ${ }^{53}$ As the rationale for its establishment was at least in part that some government departments had rat infestations, the potential humour of the proposition was clear: Hansard records two rather facetious questions directed at Boscawen, and Sir H. Brittain asked if his office files relating to the topic had been eaten by rats. ${ }^{54}$ However, the government rats had in effect employed the men and caused equipment to be bought.

The aim in instances such as this was to 'destroy' rats, i.e. eradicate them in their entirety, consistent with the new statutory framework, and the attempt produced new (if adapted) experimental environments, jobs and publications, such as Claremont's $A$ Practical Handbook on Rat Destruction (Rodent and Insect Pests Destruction Co., 1926) still being promoted by MAFF ten years later. ${ }^{55}$ But during the interwar period,

52 Kill That Rat, British Pathé, 1919, at www.britishpathe.com/video/kill-that-rat-week, accessed 11 February 2014; 'National Rat Week', Glasgow Herald, 27 October 1922, p. 5, col. f; 'National Rat Week', House of Commons Hansard, Commons Sitting Written Answers, 14 November, 1938, cc. 518-9W; 'National Rat Week', Nature (14 October 1939) 144, p. 661.

53 Claremont, op. cit. (1), p. 714; 'Notes on the analysis and use of red squill in rat poisons', read at Conference VI-Rat Officers, Journal of the Royal Society for the Promotion of Health, Perspectives in Public Health (September 1921) 42(5), pp. 311-318; images of the lab and factory environs at www. gettyimages.co.uk/pictures/member-of-staff-working-for-dr-c-l-claremont-research-news-photo-3307457 and www.gettyimages.co.uk/pictures/staff-working-for-dr-c-l-claremont-research-chemist-on-rat-news-photo-3307471, accessed 20 July 2016.

54 'Rat skins', House of Commons Hansard, Commons Sitting of Monday, 25 April 1921, Fifth Series, Vol. 141, cc. 37-38.

55 MAFF Bulletin No 78, A Selected and Classified List of Books on Agriculture, 1939. 
attempts were also made in Britain to use rat skins for profit, a remaking or recoding of rat bodies rather than erasure, which, as the then parliamentary secretary to the Board of Agriculture, Sir A. Boscawen, said, might create a market and therefore 'serve an additional incentive to rat destruction'.56 Proposed uses, discussed in 1921, included 'the manufacture of gloves for motor drivers' and also 'slippers'. Boscawen was reluctant to see this as a viable commercial prospect, but when pressed said, 'we are taking every possible step to place the use of rat skins on a commercial basis' ${ }^{57}$

In fact, there was a precedent: the New York Times had reported in 1897 that rat skins made 'a very durable leather, and are used a good deal' in America, 'much of it masquerading as kid ... There are dealers who make as many as 20,000 pairs of rat skin gloves a year, and a very good business it is'. ${ }^{58}$ The same was done with other animals considered to be vermin, such as the 'gutter cats' in New York City in 1920 when the demand for cheap furs escalated; reputedly the use of their pelts resulted in a marked drop in numbers of an animal that was considered a public nuisance, a piece of data that ecologist Colin Matheson found useful when seeking to estimate the 'statistics of stray cats' twenty years later. ${ }^{59}$ In other words, the aim was to turn what was by definition a useless creature to some human purpose and thereby hedge it around with an economic value. This was despite the fact that, because of the cultural associations of the rat, it was still necessary to pass the rat leather off as something else for this to be commercially viable.

At the start of the Second World War, rats came to be characterized less as a disease carrier (new though this image was) and picked up again the old early modern 'vermin' mantle of threat to food production, because of damage to animal feed, stored grain and crops waiting for threshing - delayed threshing caused by labour shortages resulted in higher rat populations. As a result, a rats order (no 866) was issued in June 1940 (along with similar orders re rabbits, rooks and wood pigeons) to enable the County War Agricultural Executive Committees to destroy rats. ${ }^{60}$ As John Sheail has argued, the approach to rat control then began to move onto a more empirical footing as rats became a subject of study for the Bureau of Animal Population, who, as a result of systematic observation of rat populations, argued for a much more methodical approach to the problem that would tackle rural and urban districts and seaports.

If we look back to the 1910 approach we can in fact see that the ideas about how best to manage rats through scientific investigation had already emerged before the Great War, while ideas about systematic control across rural and urban areas and the ports are present in less directed form in the 1919 Act, if only dominant from the Second World War. Taking the established need for national direction on board, the Ministry

56 'Rat skins', House of Commons Hansard, Commons Sitting of Monday, 16 February 1920, Fifth Series, Vol. 125, cc. 515-516.

57 'Rat skins', op. cit. (54).

58 Anon., 'Skins for commercial use: those of the alligator, frog, lizard, and rat find favor among manufacturers of leather goods', New York Times, 15 June 1897.

59 A.C. Laut, The Fur Trade in America, New York: Macmillan, 1921, p. 139, cited by C. Matheson, 'The domestic cat as a factor in urban ecology', Journal of Animal Ecology (1944) 13, pp. 130-133, 132.

60 See Sheail, 'Wartime rodent control', op. cit. (6), pp. 56-57. 
of Food therefore started to operate a Directorate of Infestation Control in 1943, which involved local authorities. The County War Agricultural Executive Committees also began to organize rural rat and mouse control more formally with the help of additional specialist pest officers; the Women's Land Army trained rat catchers who went out to the farms which commissioned them, the work promoted by the local press; and by 1945 Agriculture, the Ministry of Agriculture's journal, was encouraging farmers to take out rodent control contracts with the County War Agricultural Executive Committees in order to clear whole areas of rats. ${ }^{61}$

As rural rat destruction moved ever further from associations with disease and towards more pressing, if early modern, fears about access to reliable food supplies, so ecologist Charles Elton and his team became crucial. ${ }^{62}$ The Bureau of Animal Population was established in 1932 at Oxford University under Elton, who had had previous experience of investigating rodents such as voles and wood mice, and hedgehogs, in rural areas, thanks to earlier funding from the Empire Marketing Board from 1927 or 1928 to $1931 .{ }^{63}$ In his Introduction to Elton's Animal Ecology (1927), Julian S. Huxley had provided the example of the periodic rise and fall of 'plagues of mice, rats and other rodents' as a typical example of 'periodicity in numbers, which is perfectly normal for many of the smaller mammals'. During the height of the plague 'remedial measures are called for locally, and large sums of money may be spent'. Once the numbers collapse, those who set about 'the anti-rodent campaign claim the disappearance of the pest as a victory for their methods'. But this is nothing to do with the 'killing off of the animals by man', which 'either had no effect' or managed the numbers in such a way as to delay the 'crisis' and therefore prolong the plague. Only speeding up the epidemic crisis, reducing reproduction, or addressing the 'ecological status of the species' would have any real impact. ${ }^{64}$ This quantative understanding of populations formed the backdrop to the bureau's work under the umbrella of the Agricultural Research Council. They undertook a number of surveys and trials and published reports on the most effective means of baiting on the basis of the earlier work, and examination of rat behaviour. Rat poisons were analysed and studied for their effectiveness, and by observing rats closely they discovered how to condition the rat to take poisoned bait to greatest effect. At the end of the war they published a definitive methodology for the practice of rodent control based on their research findings, the three-volume The Control of Rats and Mice (published by the Clarendon Press). Edited by D. Chitty and H.N. Southern, the reach of these volumes is indicated by a valedictory description, on Elton's retirement in 1968 , as 'the model for such work all over the world'. ${ }^{65}$

61 Sheail, 'Wartime rodent control', op. cit. (6), pp. 58-61; e.g. 'Ratting time', Yorkshire Evening Post, 11 October 1941.

62 Sheail, 'Wartime rodent control', op. cit. (6), pp. 58-59.

63 P. Crowcroft, Elton's Ecologists: A History of the Bureau of Animal Population, Chicago: The University of Chicago Press, 1991, p. 10.

64 Elton, op. cit. (36), p. xvi.

65 Sheail, 'Wartime rodent control', op. cit. (6), pp. 59-60, 63; Alister Hardy, 'Foreword: Charles Elton's influence in ecology', Journal of Animal Ecology (1968) 37, pp. 3-8, 6. 
Following the Second World War, and the Agriculture Act 1947, ${ }^{66}$ the 1919 Rats and Mice (Destruction) Act was replaced in England and Wales by the Prevention of Damage by Pests Act 1949 (12 \& 13 Geo. 6. Ch. 55).67 In the wake of the United Nations Conference on Food and Agriculture, at Hot Springs, Virginia in 1943, which emphasized the urgent necessity of distributing, increasing and re-establishing food production after the war, ${ }^{68}$ the new Act aimed to tackle insects and other pest organisms as well as rats and mice, to preserve whatever food the UK had produced. It offered farmers the option of contracting pest destruction services through the county executive committees, a system much like the wartime processes that they would have become used to using. While stepping back in practice from centralized government planning and control, the Prevention of Damage by Pests Act 1949 nonetheless required local authorities to keep the number of rats and mice as low as possible, in sewers as well as above ground, and gave local authorities the power to require landowners and occupiers of land to take action in the destruction, and in keeping land free, of rodents in particular (though 'infestation' referred to 'rats, mice, insects or mites in numbers' in food in particular, which reflected the overarching agenda).

Under the terms of the new Act, the state ensured that local authorities provided training to rat catchers and to sanitary inspectors, kept records, wrote reports and undertook research into dealing with rats and mice. ${ }^{69}$ By this point, the bureaucratic and quantitative processes had become entangled in the chemical and physical processes of modern rat control, as the figures cited for justification for it and as proof that it was being carried out were discussed in the popular press and in the House of Commons. When disseminating information about the new Act at the time of publication, the Manchester Guardian stated that rats and mice caused the loss of around 2,000,000 tons of food annually. ${ }^{70}$ By 1952 it was reported in the House of Commons that the Ministry of Agriculture employed 1,104 people in England and Wales in connection with catching rats, with 979 of these employed in actually catching rats'. ${ }^{71}$ The Department of Agriculture for Scotland reported providing local authorities with $£ 21,722$ in grants, and that it had carried out 49,690 inspections, which revealed

66 The Agriculture Act 1947, at www.legislation.gov.uk/ukpga/Geo6/10-11/48/contents, attempted to support farmers during post-war reconstruction, and reflected a concern not to 'desert' agriculture in the way that was perceived to have happened in the UK after the First World War.

67 It remained on the Irish statue book; see www.irishstatutebook.ie/1919/en/act/pub/0072/index.html, accessed 14 February 2014; Sheail, 'Wartime rodent control', op. cit. (6), pp. 63-65.

68 The 1943 Hot Springs conference was very influential in shaping the post-war agricultural policies of all forty-four signatory nations, and had the declared intent of achieving 'the goal of freedom from want of food, suitable and adequate for the health and strength of all peoples', though the exact details of which types of food ought to be produced, and exactly where, worldwide, were to be established. For example, for a history of and response to this event at the time see John D. Black, 'The international food movement', American Economic Review (1943) 33, pp. 791-833.

69 Prevention of Damage by Pests Act 1949, $12 \& 13$ Geo. 6. Ch. 55, accessible via Legislation.gov.uk, the National Archives, www.legislation.gov.uk/ukpga/Geo6/12-13-14/55, accessed 11 February 2014; the Act has been amended several times.

70 Anon., 'Food damage by pests', Manchester Guardian, 24 February 1949, p. 6.

71 'Rat catching', House of Commons Hansard, Written answers (Commons) of Thursday, 4 December 1952, Fifth Series, Vol. 508, c. 161. 


\section{Karen Sayer}

13,044 infestations. The total operation was small relative to the whole of its budget, and also small compared to its interest in rabbit destruction, through the emerging use of myxomatosis, ${ }^{72}$ yet the wider shift to a public and official focus on rat control as a subject worthy of observation, and a necessary element of state work, produced knowledge (seen in posters, leaflets, articles, films), organizations, conferences, employment, legislation, technical language, labs and new or adapted material culture (traps, building designs, materials, poisons). These were the discursive trappings of institutions all dependent on the farm rat, and the figures offer an echo of the presence of farm rats in rural areas.

\section{Studying rats and cats}

After the war, to maintain an influence, researchers and consultants like Charles Elton who worked in new disciplines had to be, and were, pragmatic about the socio-economic, cultural and political context in which they operated. In fact, Elton's scientific policy work fed into the development of nature conservancy post-war. ${ }^{73}$ And the use made of the bureau's data set provides an interesting case study of the ways in which the emerging discourse of agricultural productivity became woven into scientific work, especially the emergent field of animal ethology, and the ways in which other animals became drawn into post-war models of labour. One paper, 'The use of cats in farm rat control', in the British Journal of Animal Behaviour, reveals that Elton (drawing on the work of the late Dr G. Dunkin, first director of the Agricultural Research Station at Compton from 1937 until his death in 1942), ${ }^{74}$ sought to determine the value of predators, not just poisons, in rat control by analysing field studies that had been carried out during the war under the Agricultural Research Council on several of its mixed, dairy and pig farms. These studies, which counted numbers of cats and rats in specific locations, across two to three seasons from 1939/1940 to 1942, with additional data from 1943 and through to 1945 , revealed that cats could be effective in rat control, but that their influence was highly localized; barns, ricks and cottage gardens more than about 230 metres away from cats might contain tens or even hundreds of rats. Rats, it noted, this time were generally controlled using poisoned bait, sometimes gassing, 'break-back' traps and 'block control campaigns', but Elton's study showed that they could also be controlled around farm buildings (though not in fields) through human-directed predation. In the case of large infestations, cat control had to wait until the rats had been cleared in their entirety by poison. This was explained by the rats entering a rat-free territory patrolled by cats being placed at high risk through

72 1956-57 Cmnd. 145 Agriculture in Scotland. The report of the Department of Agriculture for Scotland for 1956, pp. 43-54, 46, 79; on myxomatosis in England and Wales see John Martin, 'The wild rabbit: plague, policies and pestilence in England and Wales, 1931-1955', Agricultural History Review (2010) 58(2), pp. 255276; on rabbits see Sheail, 'Wartime rodent control', op. cit. (6).

73 According to Crowcroft, Elton successfully rewrote a grant bid avoiding the 'vague' word 'climate' and replacing the word 'disease' with 'health' under advice. Crowcroft, op. cit. (63), pp. 8-10.

74 Andrew Mackenzie, 'History of the Agricultural Research Council Institute for Research on Animal Diseases at Compton', Veterinary History (2016) 18, pp. 228-240. 
not knowing the cover, whereas established colonies would be in balance with the cats in terms of knowledge and experience, something borne out by more recent studies suggesting that cats prefer to predate smaller rats, possibly because they are easier to catch (younger and more naive). The cats also needed to be 'anchored' by feeding just enough (milk) to keep them on the farm, though not so much as to leave them with no interest in patrolling. But the number of cats was deemed by Elton to be more important than their ratting quality, and he believed that cats could be very effective at controlling rats. ${ }^{75}$

In the study as eported by Elton in 1953 it was therefore determined that it 'would seem best ... to regard cats as a useful source of additional farm labour ... [given] a general shortage of skilled labour' ${ }^{76}$ The interest for the Bureau of Animal Population therefore lay first and foremost with the rat and the cat and the ways in which they interacted. But by adopting the emerging farmwork study methodologies of the period, ${ }^{77}$ and agricultural economics, ${ }^{78}$ to interpret the data collected during the wartime field studies of rat populations, in an effort to assess and analyse all aspects of traditional farm rat control, the final paper also ultimately assessed the relative costs involved and the efficiency of using cats as compared to human beings to control vermin. Farm cats were evaluated for their efficiency as well as efficacy in terms of relative successes/skills, long-term impact, costs in food and labour (calories consumed, transport, fees) and (adopted from the new farmwork studies approaches) the psychological aspects of the work for the cat and the human labourer. The net effect was to present the cat in conclusion as 'a useful and efficient source of additional labour'79 in the same way that all other labour on the farm (horse, manual and mechanical) was accounted for at the time. Alongside the application of husbandry within post-war nature conservation, ${ }^{80}$ we therefore also see the increasing reach of the discourse of labour efficiency in the immediate post-war period, which went far beyond the advisory economists: rats, cats and labourers could all be surveyed and formally evaluated by anyone seeking to make their work useful to farmers after the Agriculture Act of 1947. It also suggests that animals other than those species farmed as livestock were occasionally captured within the thinking that underpinned post-war reorganization and the mechanization of farmwork. Though there was one letter to the Lancet in 1907 that suggested, on the basis of enumeration and careful observation, that cats could be used to keep rats

75 Charles S. Elton, 'The use of cats in farm rat control', British Journal of Animal Behaviour (1953) 1, pp. 151-155, 152-153; Elsa Bonnaud, E. Vidal, D. Zaroso-Lacoste and F. Torre, 'Measuring rodent incisors from scats can increase accuracy of predator diet studies: an illustration based on island cats and rats', Ecology/Ecologie, via Science Direct, doi:10.1016/j.crvi.2008.07.001, p. 690.

76 Elton, op. cit. (75), p. 154.

77 For example, for time-and-motion/farmwork studies of the period in the USA see Harold Clayton M. Case and Paul Evans Johnston, Principles of Farm Management, Chicago: J.B. Lippincott Co., 1953; for an example in Britain see Brian Branston, Time and Motion on the Farm, London: Faber \& Faber Ltd, c.1952.

78 Edith H. Whetham, 'The search for the cost of production, 1914-30', Journal of Agricultural Economics (1972) 23, pp. 201-211, 210-211.

79 Elton, op. cit. (75), p. 155. 'Elton viewed the use of surveys and observational methods as essential to the documentation and interpretation of species interactions.' M.A. Leibold and J.T. Wootton, introduction to Charles S. Elton, Animal Ecology (reprint), Chicago: The University of Chicago Press, 2001, p. xliii.

80 Sheail, 'Wartime rodent control', op. cit. (6), p. 64. 
down and therefore reduce the incidence of plague in India, the cats in this case were evaluated as an established capital associated with higher castes, ${ }^{81}$ rather than as labourers, so this was a novel approach and very much part of a new way of thinking about labour of all kinds. And, in this instance, if unsurprisingly given that the paper was published in the British Journal of Animal Behaviour edited by Julian Huxley and William H. Thorpe, the subjective experience of labour (cat or human) also remained in play, the cat in effect rewritten as part of the technology of the farm. ${ }^{82}$

\section{Post-war 'control'}

After the Second World War, Turnbull et al. have demonstrated that the move to higher levels of intensive production, and also more chemical application than before c.1940, impacted on the degree of biodiversity in European agricultural systems. ${ }^{83}$ The effects of these changes are complicated by the fact that some (wild) species within the farmed landscape have co-evolved with farming and are therefore dependent on specific practices within it. As Turnbull et al. state, 'some species ... in Europe where farming has been an integral part of the landscape for thousands of years, thrive in extensively managed farmland and are clearly threatened by agricultural intensification'. ${ }^{84}$ When it comes to the species affected - be they pollinators, producers, herbivores or predators - Winquist et al. suggest that it is also clear that they are normally considered to be an 'integral part of the European cultural landscape, and their loss has provoked both public and political outcry' ${ }^{85}$ By the 1960 s, scientists working in the fields of ecology and entomology in America and Canada began to look at the use of what came to be called 'biological controls' in farming and the mixing and matching of these with the use of synthetic chemical control as 'integrated control'. 86 But according to Camilla Winquist et al., increased homogeneity and reduced landscape complexity

81 A. Buchanan, 'War against rats: the value of cats', The Lancet (19 October 1907) 170, p. 1099.

82 Studies of cats were still relatively novel: W.T. Shepherd, 'The discrimination of articulate sounds by cats', American Journal of Psychology (1912) 23, pp. 461-463, described an early experiment to determine if cats could tell human vocalizations apart, but it was not until 1944 that the cat was studied for its vocalization by Mildred Moelk, 'Vocalizing in the house-cat: a phonetic and functional study', American Journal of Psychology (1944) 57, pp. 184-205. Ecologists showed an interest in wild cats in W.L. Taylor, 'The wild cat (Felis silvestris) in Great Britain', Journal of Animal Ecology (1946) 15, pp. 130-133; and Matheson, op. cit. (59). Matheson also published on rat populations: C. Matheson, 'A survey of the status of Rattus rattus and its subspecies in the seaports of Great Britain', Journal of Animal Ecology (1939) 8, pp. 76-93.

83 Sean L. Tuck, Camilla Winqvist, Flávia Mota, Johan Ahnström, Lindsay A. Turnbull* and Jane Bengtsson, 'Land-use intensity and the effects of organic farming on biodiversity: a hierarchical metaanalysis', Journal of Applied Ecology, accepted manuscript online, 30 December 2013.

84 Turnbull et al., op. cit. (83). Where pesticides drift, pollinators may still be affected on farms bordering an organic farm.

85 Camilla Winqvist*, Jan Bengtsson, Tsipe Aavik, Frank Berendse, Lars W. Clement, Sönke Eggers, Christina Fischer, Andreas Flohre, Flavia Geiger and Jaan Liira, 'Mixed effects of organic farming and landscape complexity on farmland biodiversity and biological control potential across Europe', Journal of Applied Ecology (2011) 48, pp. 570-579, 575-576.

86 Paolo Palladino, 'Ecological theory and pest control practice: a study of the institutional and conceptual dimensions of a scientific debate', Social Studies of Science (1990) 20, pp. 255-281, 255-256. 
(with a proportionally lower number of arable fields nearby) due to increased agricultural specialization has reduced the effectiveness of biological controls. ${ }^{87}$ Following the publication of Rachel Carson's Silent Spring (1962 in the USA, 1963 in Britain), these debates fed into the public and political arenas, ${ }^{88}$ just as Ruth Harrison's Animal Machines (1964) was to do two years later with intensification. ${ }^{89}$ From the point of view of farmers and agriculture's subsidiary industries, such debates created potential legal, perceptual and methodological complexities, yet also opportunities as new markets for organic products opened up.

The officially sanctioned, promoted and legislated management of vermin in the UK after the war fell within this same Europe-wide framework for the promotion of more homogenized, intensive agricultural production. That method was characterized as 'modern', and in this case modern meant clean, pristine and hygienic, while specialization of necessity relied on a number of interwoven technologies to work. ${ }^{90}$ In the UK as elsewhere, intensive livestock and poultry production therefore emphasized the need to keep the animals and birds free from disease and predation. As Gray stated in Diseases of Poultry, hygiene and sanitation 'will preserve a bird in complete health and secure its maximum output'. 'Even if the stock is healthy and sound', he continued, 'it is a living thing, and though ... intensive methods of rearing may increase the output ... the effect upon their tissues is to reduce their health and seriously impair the vitality of the strain. Knowledge of the principles of hygiene and sanitation will prevent this'. ${ }^{91}$ The idea that animals should not be pushed too hard existed before Animal Machines, ${ }^{92}$ but support for this farming method included arguments that it was actually better for the farm animals housed in these systems because they were protected by them.

No one can see the world from the hen's point of view, W.P. Blount had argued in Hen Batteries, but the experienced poultry farmer could recognize the sounds that the hens make to express 'contentment or dissatisfaction'; the calls that he had heard, Blount said, were all representative of 'cheerful and inquisitive', i.e. happy, birds. ${ }^{93}$ That contentment was grounded in the idea of preventive welfare secured by progress and evidenced by the physiological response of the birds (good health). It is in fact clear from the outset of the debate about intensification that many farmers and veterinarians themselves laid claim to a genuine interest in the well-being of stock, on the basis that animals

87 Winqvist et al., op. cit. (85). Winquist et al. found the greatest diversity and richness of plant and bird species in landscapes that were both subject to organic farming practice and more complex, but this was not the case for ground beetles.

88 Paolo Palladino, Entomology, Ecology and Agriculture: The Making of Scientific Careers in North America 1885-1985, Amsterdam: Harwood Academic Publishers, 1996, pp. 1-2; John Sheail, An Environmental History of Twentieth-Century Britain, Houndmills: Palgrave, 2002, pp. 235-236.

89 Sayer, op. cit. (11).

90 William Boyd, 'Making meat: science, technology, and American poultry production', Technology \& Culture (2001) 42, pp. 631-664, 633, 634.

91 E. Gray, Diseases of Poultry: Their Aetiology, Diagnosis, Treatment and Control, 4th edn, London: Crosby Lockwood and Son, 1955, p. 39.

92 Abigail Woods, 'From cruelty to welfare: the emergence of farm animal welfare in Britain, 1964-71', Endeavour (2012) 36, pp. 14-22, 20; Sayer op. cit. (11).

93 W.P. Blount, Hen Batteries, Bailliére: Tindall \& Cox, 1951, p. 247. 
in industrialized modern agricultural systems were protected from the vagaries of nature - including illness, food shortages and attack by their own kind and/or other animals. ${ }^{94}$ Rats were well known to tunnel underneath chicken coops outdoors, where ratting dogs could be set to catch them. ${ }^{95}$ Particular forms of farming generate particular forms of infestation control, and both rats and mice became subject to more systematic forms of control as a result of intensification.

However, though few commentators mourned the loss of rats, attempts to control them as vermin did impact on high-value species and cause an outcry. In the case of poisonous applications in vermin 'control', these brought their own risks for the human user and livestock, not just the rats. As already indicated, some forms of 'control' could cause illness and injury to livestock and be a cause of occupational illness for farmers and farm workers. In its fourteenth edition, Fream's observed, for example, that on 'many farms, poisonous substances are in routine use and may be accidentally eaten by stock with disastrous results. ${ }^{96} \mathrm{By}$ the end of the nineteenth century, in parallel with the emergence and provision of technical agricultural education in Britain, which it was believed at the time had lagged behind other European states, Fream's was the first British general agricultural textbook, published as William Fream's Elements of Agriculture: A Text Book (1892). Nicholas Goddard has shown that, with a Preface that cited the scientific expertise of Miss Ormerod and Dr Voelker, ${ }^{97}$ it quickly became, as hoped, a standard work. It sold over 20,000 copies in its first year and ran through several reprints on first publication and subsequently continued through multiple editions and revisions to the end of the twentieth century. ${ }^{98}$

Through a text like Fream's, we can observe subtle changes and continuities in agricultural practice. Standard texts like this, and books of animal husbandry in the same scientific and technical tradition, often described the symptoms caused by various forms of rat poison, alongside the symptoms of over- or incorrect feeding, disease and injury in livestock. The hazard had become more commonplace in the 1940s, as the use of poisoned baits increased. Hence another standard text of the period, Ernest Gray's Diseases of Poultry (first edition 1940), observed that the 'increased use of vermin baits since the war has been responsible for some heavy losses among flocks which accidentally consumed them'. And he highlighted arsenic and phosphorus as key rat poisons. ${ }^{99}$ Gray also described what he called 'vegetable poisons', which were also put out for rats - 'ground nux vomica seeds' that led to strychnine poisoning. However, though he detailed the symptoms of poisoning, and suggested sending the

94 For example, Luther Tweeten, Terrorism, Radicalism, and Populism in Agriculture, Ames: Iowa State Press, 2003, p. 102.

95 'Ratting on derelict poultry farm', J.C. Brocklebank, Glos. rat, rabbit and weeds officer, black-and-white photograph of men, having tipped up a hen house, letting dogs underneath to chase rats, MERL H.20, 9/40.

96 Robinson, op. cit. (16), p. 698.

97 W. Fream, Elements of Agriculture: A Text-Book Prepared under the Authority of the Royal Agricultural Society of England, London: John Murray, 1892, Preface.

98 Nicholas Goddard, “"Not a reading class": the development of the Victorian agricultural textbook', Paradigm (1997) 23, e-text at http://faculty.education.illinois.edu/westbury/paradigm/goddard.html, accessed 12 December 2013.

99 Gray, op. cit. (91), p. 106. 
carcasses for testing, presumably to prevent recurrences, he did not see treatment of the individual bird as 'an economic proposition'. ${ }^{100}$ At this point, the new economies of scale for wartime food production had already begun to emerge among the audience for this type of advice, and this thinking continued after the war.

Textbooks like this and Fream's provide us with a vivid insight into the changing animal management and wider farming practices of their day. Adverts for rodenticides in farmer's periodicals like Farmer \& Stockbreeder, or Farmer's Weekly, along with illustrated articles, promoted the latest techniques and services as efficient (building on postwar labour studies and accounting). With slogans such as 'science defeats the rat', the effects of a product like Ratero seem almost implacable and certain to benefit the farmer. ${ }^{101}$ But while each practice continued, as it did despite the advertising and publication of new advice, the specialist literature had to highlight the possible (accidental) consequences of all the old methods alongside descriptions of emerging issues. We therefore see Leonard Robinson, in Modern Poultry Husbandry, explaining,

Cases of poisoning in poultry are reported from time to time, frequently as a result of the birds obtaining access to rat poisons containing compounds of phosphorous and/or arsenic.

In the Veterinary Record (May 1945), Blaxted and Gordon state that the four commonest causes of acute poisoning in poultry are phosphorous, arsenic, zinc phosphide and cacaobean residues.

The greatest care should be taken when using rat poisons of the above types, which though placed out of reach of the birds, may be carried into the poultry run or house by the rats.

Certain rat poisons contain Salmonella organisms, which, while having no apparent effect on the birds, may cause them to react to the blood test for B.W.D.

Recently an effective and completely safe method of rat and mouse destruction has been found in Warfarin. ${ }^{102}$

In the texts that describe the latest farming methods, through warning and the identification of danger we find incidental traces of the pre-existing, commonplace and preferred methods in use.

As told in his account of the process for the heart journal Circulation, Karl Paul Link and his team at the University of Wisconsin developed Warfarin in an effort, on and off from 1942 onwards, to produce a rat poison derived from the active agent of naturally occurring anticoagulants in badly cured clover hay. The hay had been brought to him in 1933 by a farmer whose cattle were haemorrhaging due to this 'sweet clover disease'. The substance was patented in 1948 in the USA by the Wisconsin Alumni Research Foundation (WARF), and Warfarin (3-phenylacetyl ethyl 4-hydroxycoumarin) was registered and launched as a rodent poison in America in 1948. Similar compounds and agents were also being developed in Europe at the same time and these led Link to also experiment further with Warfarin for clinical purposes in the treatment of (human) heart disease in 1949 and 1950, despite some initial debate among researchers

100 Gray, op. cit. (91), p. 107.

101 For example, 'Murphex Warfarin' and 'Ratero' advertisements, Farmer \& Stockbreeder, 20 May 1952, pp. 30-31; 'Ratin service' advertisement, 10 June 1952, p. 32.

102 Leonard Robinson, Modern Poultry Husbandry, London: Crosby Lockwood \& Son Ltd, 1957, p. 676. 
and clinicians about its efficacy. ${ }^{103}$ By 1951 Warfarin was a commonplace in American agriculture, and by 1957 it had been widely adopted by American farmers. ${ }^{104}$ In Britain Warfarin was also quickly adopted as a rodenticide and was subsequently tested on grey squirrels. ${ }^{105}$

Despite statements in texts such as Robinson's, and though Link argued at the time that it was 'the safest rodenticide known' for human users, ${ }^{106}$ it gradually became clear that Warfarin had to be used carefully on and off the farm to avoid harming other species. In addition, Warfarin came to be used so widely to control rodent populations that by the late 1960s and the 1970s resistance had begun to develop in rats and mice throughout Great Britain. The physiological response of the rodents, co-evolving to address human control, was studied in the UK in collaboration with the University of Wisconsin. Ecological field studies were undertaken in Wales, and a second generation of anticoagulant rodenticides was developed in the lab and via field trials by 'chemical and pharmaceutical companies and in collaboration with the World Health Organization', shaped by rat behaviour and response to human predation. ${ }^{107}$ In essence, the history of rat control was reprised in these studies. As before, when rat populations were studied across the UK, rats were found to inhabit farmland and farm buildings in the South East, the East Midlands and the East of England, with the highest populations in buildings housing cereals and on land growing 'cereals, and root, fodder and vegetable crops'. ${ }^{108}$ This was exactly as it was in the 1919 Parliamentary debate, which suggests that for the rat new farming methods and mechanization had had little impact, though intensive poultry farmers were finding that poultry houses offered particularly favourable conditions for mice. Mice therefore emerged as a more significant problem under intensive production, i.e. they became a significant pest for farmers because of the mode of production, not because they had changed. Within other parts of the sector, as a form of pest control they were said to be a useful animal. For example, it was observed in the fifteenth edition of Fream's in 1972 that mice could help arable and horticultural farmers, and fruit producers. 'Mice', Fream's stated, 'voles, shrews and hedgehogs, together with reptiles, lizards, frogs and toads also play a part in keeping down the numbers of insects'. ${ }^{109}$ In its descriptions of pests and disease Fream's captures the way in which farming still had a very complex profile throughout this period.

103 Karl Paul Link, 'The discovery of Dicumarol and its sequels', Circulation (1959) 19, pp. 97-107; see also M. Scully, 'Warfarin therapy: rat poison and the prevention of thrombosis', The Biochemist (2002), pp. $15-17,15$.

104 F.A. Pearson, W.I. Myers and S.W. Warren (New York State College of Agriculture), Farm Economics (March 1951) 179, pp. 4638-4642, 4641; E.M. Rogers, 'Categorizing the adopters of agricultural practices', Rural Sociology (December 1958) 23(4), pp. 345-354, 349: using data from an Ohio study of Warfarin use, Rogers gave the percentage of adoption completed as 78 per cent.

105 MAFF, Pest Infestation Control: Combining the Report of the Infestation Control Laboratory 1968-70 and Pest Infestation Research 1970, London: HMSO, 1973, p. 70.

106 Link, op. cit. (103), pp. 104-105.

107 MAFF, op. cit. (105), pp. 49-50, 52-54, 55-56.

108 MAFF, op. cit. (105), p. 51.

109 MAFF, op. cit. (105), pp. 54-55; Robinson, op. cit. (16). 


\section{Conclusion}

By the 1970s there was a systematic quantitative approach to rodent control that had been developed through close observation of rodent behaviour and movement which remained a research tool in pest control - coupled with the application of anticoagulant rodenticides. As part of this, new positions and projects were developed: population studies and rodent 'control' came together in the mid-1970s in new jobs at the Pest Infestation Control Laboratories dotted around the country, designed to study what New Scientist termed in 1972 'super rats', and in research to create new products, such as 'chemosterilants' (synthetic hormones) aimed at controlling rat reproduction, hailed by New Scientist in July 1973 as a 'perfect rat poison at last'. ${ }^{110}$

However, because of the post-Second World War acceptance of the significance of the rodent problem to all agricultural producers, and in towns and cities, and subsequent almost universal and effective use of anticoagulants based on observed rat behaviour, not only had rats become resistant, but also Warfarin residues had come to be detected beyond the boundaries of the farm. ${ }^{111}$ The 1973 MAFF Pest Infestation Control report noted that some birds may have been killed by Warfarin, though after testing on pheasants and pigeons in controlled conditions it was concluded that at that point the evidence was not strong enough to prove the theory. However, because of the known difficulties with organophosphorus compounds like PCB and organochlorine compounds such as DDT, and the difficulty of detecting anticoagulant compounds in tissue samples, the issue remained live. ${ }^{112}$ Indeed, the report states that much of ' 1968 and 1969 was taken up with the preparation of the "Further Review of Certain Organochlorine Pesticides" which was published in December 1969. A significant part of this report was an appraisal of the risks to wildlife'. ${ }^{113}$ Subsequently, companion animals were found to be at risk from anticoagulants, and wild populations of predators, such as foxes, barn owls, red kites and kestrels, were also found to eat exposed bait meant for the rats, or consume rats that had taken poisoned bait and travelled beyond the farm's buildings, off the farm or around its fields and along its banked and hedged boundaries. In 1983 testing for second-generation anticoagulant rodenticides was therefore established, and both producer- and government-sponsored agencies developed guidelines on their safe use and further programmes of testing through the Predatory Birds Monitoring Scheme (PBMS) and, in cases of fatality, the Wildlife Incident Investigation Scheme. ${ }^{114}$ Meanwhile, the numbers of rodents themselves seem to have

110 J. Greaves, 'How super rats survive', New Scientist, 19 October 1972, pp. 156-158; anon., 'A perfect rat poison at last?', New Scientist, 19 July 1973, p. 125; also advertisements for government posts: New Scientist, 5 December 1974, p. 775, 15 May 1975, p. 413, 1 June 1978, p. 789.

111 Elton does not discuss the consequences for cats of the use of (pre-Warfarin) rat poisons.

112 MAFF, op. cit. (105), pp. 41-49.

113 MAFF, op. cit. (105), p. 37.

114 L.A. Walker, N.R. Llewellyn, M.G. Pereira, E.D. Potter, A.W. Sainsbury and R.F. Shore, 'Anticoagulant rodenticides in predatory birds 2010: a predatory bird monitoring scheme (PBMS) report' (2012), Centre for Ecology \& Hydrology, Lancaster, UK, at https:/wiki.ceh.ac.uk/download/attachments/ 134414860/PBMS_Rodenticide_2010_Final.pdf?version=1\&modificationDate $=1332940895000$, accessed 7 February 2014; 'Pesticide poisoning of animals 1998: investigations of suspected incidents in the United 
remained steady between the 1970s and 1990s according to the National Rat Survey. ${ }^{115}$ The scientific management of the spaces of the farm that evolved from 1910 essentially led to the need for additional observation and testing off-farm, and therefore central oversight, as farm pest-control practices bled into what was deemed to be off-farm. The perceptual purity of modern agricultural 'hygiene', however, drew in agencies such as the Pest Infestation Control Laboratory (established in 1970 through a combination of personnel and resources from MAFF's Infestation Control Laboratory and the Agricultural Research Council's Pest Infestation Laboratory), which reflected the highly integrated nature of agricultural production. Farm 'hygiene' became implicated in a process that involved observing the effects of pest control on wildlife, and reporting to bodies such as the Wild Life Panel of the Scientific Subcommittee. Post-war farm management had thus also become wildlife management, with pests such as the rat inhabiting and crossing freely between these overlapping spaces, which demonstrates very clearly the interconnectivity of and biotic flows across and through farms and their rural locations.

Occasionally a sympathetic rural rat emerged in British culture during this period. Miss C. Tudor depicted rats in three pieces - Jimmy Bell's Cobbler's Shop during the 1930s (date unknown), Rats and Flower Sack (1945), and Rats and Boots (1947) where rats inhabited human spaces comfortably (without human figures or terriers) and behave just like rats. They are not the subjects of either sport or horror, but of knowing observation. ${ }^{116}$ A polarizing animal for its human observers, it is the simple inversion of the fact that rats are predominantly detested, not loved, and were always harassed that makes Richmal Crompton's children's story 'William the rat lover' in William the Detective entertaining. ${ }^{117}$ However, as the Crompton story implies, the rural rat was mostly seen as threat, and as such was killed, in multiple ways.

Tracing the histories of rat control in twentieth-century Britain, we see the highly integrated nature of the knowledge networks in and around agriculture, and the dynamic and interconnected relationships between farmers, livestock, wildlife, 'vermin', scientists, commercial enterprises and policy makers. In rat-control policies, we come to see 'the farm', though bounded by hedges and fences, as part of a much greater system.

Kingdom. A report of the Environmental Panel of the Advisory Committee on Pesticides', at www.pesticides. gov.uk/Resources/CRD/Migrated-Resources/Documents/W/WIIS_1998.pdf, accessed 7 February 2014. See also Major Scheme Publications Produced since 1976, at www.pesticides.gov.uk/guidance/industries/ pesticides/topics/reducing-environmental-impact/wildlife/major-scheme-publications-produced-since-1976, accessed 7 February 2014.

115 'Rat infestation', House of Lords Hansard, Written answers (Lords) of Monday, 1 July 1996, Fifth Series, Vol., 573, c. WA86.

116 C. Tudor, Jimmy Bell's Cobbler's Shop during the 1930s (date unknown), oil on board, $35 \times 43 \mathrm{~cm}$; Rats and Flower Sack, 1945, oil on board, $34 \times 46 \mathrm{~cm}$; Rats and Boots (1947), oil on board, $34 \times 44 \mathrm{~cm}$, all bequeathed to the Lakeland Arts Trust collection by Miss C.E.F. Tudor, 1992 (the artist's daughter). No further details are available, reference email from Suzannah Brown, documentation assistant, Lakeland Arts Trust collection, of 09:45, Thursday 2 July 2015, to the author.

117 Richmal Crompton, 'William the rat lover', in Crompton, William the Detective, London: George Newnes Ltd, 1935. In this story the protagonist William Brown, on being horrified at the destruction of rats during national 'Rat Week', promotes and cares for the creatures in his "Rat Fortnight" - itself an alternative to a week dedicated to the care of birds. 
Rats were the focus of knowledge within specific sites/spaces and contexts, and for particular specialisms, producing expert knowledge(s), expertise and experts, but tracing their histories we find the pasts of other animals too. Moreover, following the rat takes us rapidly beyond national boundaries. Dominant understandings, perceptions and knowledge(s) about rats circulated worldwide. Those understandings ranged across the discourses of art, newsprint, specialist publications, official reports, Parliamentary debate and legislature, and often included a human use, with economic value: income generation (killing rats and using skins, ratting), as well as disease, food shortage and cost. As pests/vermin that destroyed/spoiled/ate farm and other produce, they had already produced knowledge for expert rat catchers who had to observe them in order to 'destroy' them. Under intense national focus of study in Britain c.1910-1918, due to plague, their movements became key. In the Second World War, subject to anxieties about food shortages, the idea of the rat as enemy played into control campaigns designed to erase them. Post-war rats went on to influence the built spaces of the farm framed by hygienic modernity in choice of preferred materials (concrete, sheet metal, wire). This was a rat-proof aesthetics: puritan, clean and practical. Though new versions of old methods emerged, such as ever new designs for traps, ${ }^{118}$ or the use of Warfarin as poison, the actual methods of destruction/control remained by and large the same, and the warnings in the agricultural texts show us that often the actual products remained in use long after their supposed replacement by new and improved forms. Even the use of cats to control farm rats was in effect a formalization of what was already known, because both earlier and later knowledges were founded on the human observation of the same creature. Chemical sterilization was the one new offer, at which point, exactly like livestock, farm rats' housing, feeding and even reproduction were subject to oversight by farmers. But what also changed was a shift away from 'destruction' to 'control' in almost a recognition of human limits, a symbolic nod towards the rodents: commensal rural rats must of necessity (reluctantly) be lived with; just like livestock, to be kept in their place. And 'control' relied on the technology of systematic quantification, statistical analysis and a new interweaving of vermin control with labour efficiency, delivered through ever specialized work packages and new sites of rat-dedicated labour: farm and hedgerow, but also lab, office, manufactory. 